\title{
Islamic Perspectives
}

\section{Homosexuality-An Islamic Perspective}

\author{
M. Basheer Ahmed, M.D.
}

DOI: http://dx.doi.org/10.5915/38-1-6275

\section{Fort Worth, TX}

Abstract: Homosexuality can be defined as a sexual orientation and a sense of personal and social identity with or without alternative life style. Homosexuality was regarded as an illness, but in 1973 it was removed from Psychiatric diagnostic categories. The majority of psychiatrists believe that homosexuality is an alternative life style rather than a mental disorder. It needs to be clarified that the expression of homosexuality (behavior) is a matter of choice, which is under one's control.

Islam and other major religions condemn homosexual behavior. Homosexuals are not emotionally disturbed or socially dysfunctional. If they are engaged in a homosexual act, they are committing a prohibited act which is a major sin. They are committing a sin which is similar to a heterosexual individual who indulges in a sexual relation without marriage. Islam teaches self-restraint.

As Muslims, we do not make religious laws, but we obey God's commands. We cannot impose our views on others but we know the clear instructions from Qur'ān about homosexual behavior and we have a duty to teach the correct teachings of Qur'ān.

\section{Muslim physicians and clinicians must have a non-judgmental attitude to help individuals who are suffering the consequences of their behavior. A homosexual patient may be suffering from any illness, including Acquired Immune Deficiency syndrome (AIDS). A sick homosexual patient is a person entitled to treatment with dignity and respect. When personal attitude interferes with our optimal doctor-patient relationship, the ethical course is to refer the patients to other colleagues.}

Key Words: Homosexuality, Islamic perspective, role of clinicians.

\section{Introduction}

Homosexuality is defined as one's desire for sexual contact with a person of his/her own sex.

Homosexuality means, the sexual orientation and fantasies, with or without overt sexual behavior with same sex partner. Homosexuality in women is called lesbianism and men are usually referred to as gay. Bisexuals are primarily heterosexuals but they also manifest homosexual desires and behavior. Homosexuality is one of the most difficult subjects to discuss because of societal taboos and the fact that most religious traditions vehemently damn

Private practice of psychiatry and former professor of psychiatry at Southwestern Medical School Correspondence: Dr. M. Basheer Ahmed 10 Homeplace Ct Arlington TX. 76016 Email: mbahmedo3@hotmail.com such practices. Until the 1970 s the academic community viewed homosexuality as an illness and a sexually deviant behavior. A personality disorder; characterized by a deeply ingrained maladaptive pattern of behavior was regarded as a causative factor. Now, under the light of new biological and sociological data it is no longer regarded as a sexual disorder or mental illness. Homosexuality was removed from Psychiatric diagnostic categories by the American Psychiatric Association in 1973. The majority of the psychiatrists view homosexuality as a sexual orientation problem and an alternative life style rather than a mental illness. It needs to be clarified that homosexual orientation may be caused by biological and/or psychological factors, but the expression of homosexual behavior is a matter of choice which is under one's control. It is my opinion that the human 
See partial retraction dated July 4, 2015 at http://dx.doi.org/10.5915/44-1-14774

being has a capacity to control sexual behavior no matter what sexual orientation he/she has.

Homosexuality has been noted since antiquity. It is recorded in Greek and Roman history and it is described as a sinful act in all Abrahamic religious books: Torah, Bible and Qur'ān. Homosexuality appears to be uniformly distributed in all the human beings, irrespective of ethnicity, religiosity and nationalities. However the visibility of homosexual behavior varies considerably by nation, culture and ethnicity. In the United States during the last 30 years, due to increased tolerance and a general openness in society, more homosexual individuals are feeling comfortable and therefore "coming out." As a result, homosexual groups have developed a strong identity and gradually became a political force. The American homosexual rights movement has pushed the limits of acceptable sexual behavior for all people and pushed for acceptance of non-conformity and alternate lifestyles.

In 1948 , Kinsey found that $10 \%$ of men and $5 \%$ of women are homosexuals. Kinsey also reported that $37 \%$ of individuals have adolescent homosexual explorations. Although accurate data on sexual preferences is difficult to obtain, some other surveys report the lower figures of 3-6\% prevalence of homosexuality in male and 1-2\% in females. In cultural studies, Ford and Beach found that homosexual behavior was socially accepted in 76 societies. However, in most societies homosexual behavior is not acceptable. ${ }^{2}$ Some men may engage in homosexual behavior (as in prison or in the navy) but their sexual orientation may be heterosexual. In certain cultures homosexual activity is permitted in young boys until adulthood when it is stopped and they are allowed to marry women. In certain cultures due to lack of acceptance and the stigma associated with being gay, some men resort to adopting the opposite sex role (as males living as females) while others cross dress and some become male prostitutes.

Some homosexuals do engage in homosexual behavior. Others do not commit such acts because of inhibitions due to religious and social influences as well as intrapsychic conflicts. Some men show no interest in the opposite sex and at the same time show no homosexual fantasies due to denial.
The current concept of homosexuality, which is defined as homosexual orientation and homosexual behavior, is the product of the 20th century. Now, it has become a sexual identity and a political movement. Homosexuality is probably universal in humans but institutionalized forms of homosexual activity is not. ${ }^{3}$

\section{Causes of Homosexuality}

Biological, psychodynamic and environmental factors have been implicated in causing homosexuality.

\section{1) Biological factors}

Review of the data on biological and hormonal studies in homosexuals suggests that biological factors may contribute to the development of the condition which modifies the sexual object. This data seems to support the hypothesis that androgen may be deficient in male homosexuals. Hormonal factors (gonadal and adrenal hormones, hormone receptors, neurosteroids and neurotransmitters, etc.) play a determining role in the formation of gender identity in fetal life.

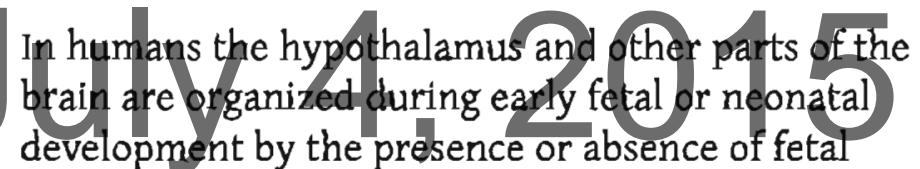
development by the presence or absence of fetal androgens. They affect both physiology and behavior that is sex specific. Fetal androgens during the critical period organize the hypothalamus for later acyclic gonadotrophin production, male reproductive behavior and masculine social behavior. The absence of fetal androgens results in later cyclic gonadotrophin production, female reproductive behavior and female social behavior. Both physiology and the behavior can be reversed by reversing the critical period androgen exposure, regardless of chromosomal or gonadal sex. Males are biologically more vulnerable to the disruption of sexual function than females. One reason is that male and masculine development requires that something be added to the basic C.N.S predisposition toward femaleness.

Genetic studies have found a higher incidence of homosexual concordance among monozygotic twins than dizygotic twins, which also suggests a genetic predisposition. Hamer tested the DNA patterns of homosexuals and located a region near the end of the long arm of the X-chromosome that he believed 
was likely to contain a gene influencing sexual orientation. He identified the site as Xq28. ${ }^{4} \mathrm{~A}$ team of researchers at the University of Western Ontario Canada found no such evidence of the so called "Gay Gene" directly contradicting the studies of Hamer that pointed a specific genetic marker on the chromosomes linked to homosexuality in men.

Many scientists claim that genetic factors are an insufficient explanation for the development of sexual orientation..$^{5}$ There are numerous reports of a particular gene or chromosome associated with behavioral traits. It is extremely hard to prove the linking of specific genes to a complex human behavior. Quite often the findings have to be replicated with a much larger sample. Even if the above findings are confirmed, it only shows the genetically determined trait. Does the biological pre-disposition towards a specific behavior in itself make that behavior normal? It is also said that alcoholism and obesity are genetically determined. Does that mean that individuals have no control over their drinking and eating habits? So far the only effective treatment for alcoholism and obesity is self control.

There is a growing understanding that the interac tion of genes and the environment is much more complicated than the simple "violence gene" and "intelligence gene". Complex behavioral traits are the product of multiple genetic and environmental antecedents. An individual with genetic tendencies is more likely to become gay in a large urban area than in rural area with a strong religious environment even if they carry the same genes. ${ }^{6}$ In the current environment, it will not be surprising if child molesters claim their preference for young children is genetically determined and therefore they cannot resist these tendencies.

\section{2) Psychological factors}

Freud viewed homosexuality as an arrest of psychosexual development. Some psychodynamic factors include fixation on the mother and lack of effective fathering. Some feminine behavioral traits may be caused by strong identification and fixation on the mother.

3) Environmental and Cultural influence An overprotective, possessive and domineering mother may minimize the adolescent boy's masculine interest. A detached, unaffectionate or absent father may have some influence on the male psychosexual development as well.

Homoerotic activity may occur at all developmental stages in both boys and girls, and it is part of sexual curiosity and experimentation. This behavior is not an indication of homosexuality.

Similarly some young men, who have low selfesteem and feel themselves inadequate or weak com pared to other young men, may unconsciously think, "I am not masculine therefore I am feminine and homosexual." In the current environment, these young men are easily influenced by others. These distressed individuals can be helped by psychological support.

Some young men may be sexually exploited in homosexual behavior. Young students under the influence of a homosexual teacher may fall into this category. In a recent research study, $20 \%$ of individuals who
had a homosexual teacher said that they were influ-
enced to regard homosexuality as socially acceptable and $4 \%$ said that the teacher influenced them to try homosexuality. One percent of the individuals reported that they had sexual relations with at least one of their teachers. Twelve percent of men and $4 \%$ of women said that a teacher made sexual advances towards them. The finding that homosexuals more frequently reported homosexual sex with teachers suggest that homosexuality can be acquired by sexual interactions with other sexually-active homosexuals. ${ }^{7}$ Schools are teaching that homosexuality is normal, and public libraries advertise their gay and lesbian collection of books featuring fiction, biography, health, parenting, religion, art and books for children of gay/lesbian parents.

The feminist movement also indirectly promoted lesbian behavior because it essentially dismisses men for sexual, social and emotional needs. The movement also negates any psychological or sex linked differences. The sexual identity conflict may be expressed in lesbian behavior. 
Gay pride parades and similar gay right movements further encourage the homosexual behavior in individuals who are not exclusively homosexual.

Transient Homosexuals

Sexual experimentation of adolescent males may lead to transient homosexuality. Similarly in an isolated, exclusively male environment (e.g. navy, submarines and prison), transient homosexual behavior may occur.

Whatever the scientific validity of the research on causation of homosexuality is, it only talks about biological and psychological factors resulting in homosexual orientation. However, homosexual behavior depends upon the degree of control and the ability to sublimate one's sexual desire, that is, to divert the expression of instinctual desires or impulses from its primitive form to one that is considered more socially or culturally acceptable.

Homosexuality and Mental Health An individual who has a homosexual orientation is not different from the individual who has a hetero sexual orientation. Homosexual orientation is not symptomatic of an illness. However there is an emerging consensus from recent studies that young people who are engaged in homosexual behavior are at an increased risk of mental health problems and suicidal behavior, such as:

1. Confusion associated with homosexual feelings

2. Stresses associated with homosexual behavior

3. Rejection by family, friends and society

4. Lack of social support

5. Academic and job related problems

6. Fear of AIDS

7. Suicidal attempts of homosexual friends.

8. Depression and suicidal ideations. ${ }^{8-10}$

Homosexuality and AIDS

AIDS is caused by the Human Immune Deficiency Virus (HIV) virus. This disease is spreading rapidly in the US and many parts of the world since the early 1980s. Initially it spread among men who engaged in homosexual behavior and, unfortunately due to political reasons, it became associated with gay men. Later it spread among bisexuals and heterosexuals who have sexual relations with multiple sex part- ners. Homosexual behavior, sexual promiscuity and intravenous drug use are responsible for the rapid spread of this deadly disease. A small number of individuals developed AIDS due to infected blood transfusion and a few acquired it through perinatal vertical transmission from an infected mother. According to the United Nations, 19 million people have died of AIDS over the last 2 decades. In the U.S. death due to AIDS has declined in recent years, but the rate of new cases with HIV infection has increased. The newly developed combined anti-viral therapy is delaying the development of full blown AIDS in HIV infected individuals. Approximately $70 \%$ of the new HIV infections occur among men, of whom $60 \%$ have had homosexual relationships, $25 \%$ are I.V. drug users and $15 \%$ are heterosexuals with multiple partners.

Homosexuality and Islam

All monotheistic religions of the world (Judaism, Christianity and Islam) prohibit homosexual behavior and regard it as a major sin.

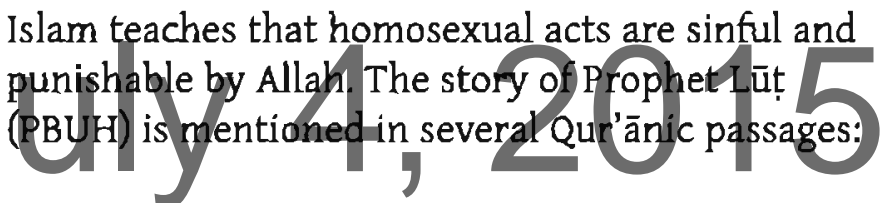

Will you [people of Lüt] fornicate with males from among the creatures of the worlds and leave these women your Lord has created for you to be your mates? Nay you are people who have transgressed all limits!" They replied "If you do not stop, O Lüt, you should become one of the expelled'.... We rained down on them the rain of brim stones; and evil was the rain which fell in those who were forewarned."11

The Qur'ān has mentioned in several passages condemnation of homosexual behavior:

We also sent Lüț: he said to his people, "Do you commit adultery as no people in creation ever committed before you? For you practice your lusts on men in preference to women; you are indeed a people transgressing beyond limits." 12

There is nothing mentioned in the Qur'àn about lesbianism. Though not mentioned specifically, it is equally condemnable as male homosexuality in the 
See partial retraction dated July 4, 2015 at http://dx.doi.org/10.5915/44-1-14774

eyes of $\operatorname{sharī}^{-1} a$ (Islamic jurisprudence) according to the principle of qiyās (analogical reasoning).

According to the Prophet Muhammad (PBUH), “...... the curse of Allah be upon he who has sexual activity with an animal and he who performs the actions of the people of Lūt.."13

From these Qur'ānic verses and this hadith, it is clear that homosexual behavior is condemned and prohibited. Active homosexuals' moral behavior shows degradation due to their fulfilling of prohibited sexual acts for sexual gratification. Heterosexual behavior is acceptable, but Islam also prohibits and condemns heterosexual behavior among unmarried people. The heterosexual impulses are present in many young adults and, in this country, heterosexual relations among consensual unmarried adults are legal. Islam prohibits such actions, and we need to abide by the religious laws. Similarly one should refrain from performing homosexual acts even though one may experience homosexual thoughts and feelings.

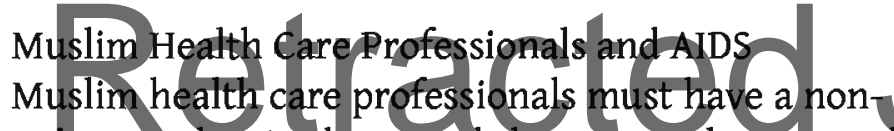
judgmental attitude towards homosexuals. We need to show an understanding and a sense of responsibility to treat all individuals, including those who are HIV-infected or have AIDS. A sick homosexual is a sick individual who is entitled to treatment with dignity and respect. Our responsibility is to treat and protect human life in all circumstances, and we must extend medical care to the virtuous as well as to the sinners. We may not approve of the sexual behavior personally, but as physicians our responsibility supersedes our personal beliefs. For some physicians it is difficult to show a non-judgmental attitude. Health care professionals are human beings with their own prejudices, inhibitions, conflicts and attitudes. When personal attitudes interfere with an optimal doctor-patient relationship and impact patient care, the ethical course is to refer the patient to other colleagues.

The Muslim Community and Homosexuality Allah has recognized men who have no sexual impulses towards women. Qur'ān says to women, "Do not display your ornaments and beauty to any- one except your husbands, fathers, brothers ... and male attendants who lack sexual desires for women."14

Tolerance does not equal acceptance. One needs to understand that having homosexual orientation does not disqualify an individual from being a Muslim. It is the homosexual behavior which is a sinful act and is prohibited. One should not outcast or reject troubled people who are engaged in sinful behavior. Hate and rejection will not show anybody the right path. We should not make judgments about their faith in Islam. Let Allah alone be the judge.

Teaching about homosexuality in sex education lessons in schools may be appropriate as long as it does not challenge the normality of the traditional heterosexual family by promoting homosexuality. Open homosexual behavior threatens the basic Islamic values and should be prohibited. Homosexual behavior is a sinful act similar to heterosexual behavior among unmarried couples. The punishment for zinā (fornication) and homosexual behavior is the same in shar ${ }^{-1} a{ }^{15}$ We cannot change religious laws just because of a changing social context. Some homosexuals never engage in homosexual behavior and remain celibate and sublimate their sexual desires by turning towards spirituality and voluntary work. Psycho-sexual counseling during the early stages of homosexuality, prior to commitment to homosexual behavior and lifestyle, helps in changing sexual orientation. Recently, psychiatrists from Columbia University in New York have reported success in treating homosexuals who show a strong commitment to change their sexual orientation. ${ }^{16}$

\section{Challenges of "Gay Positive" Environment}

Our youth are facing numerous challenges. They are surrounded by peers whose social and moral norms in this society conflict with the teaching of Islam.

They are taught that homosexuality must be treated as normal behavior. People have freedom to choose, and some people who have homosexual orientation choose to have male sexual partners. School libraries have numerous books and magazines promoting gay/lesbian behavior. Teachers are encouraged to include gay-positive information to reduce stigma 
and increase toleration in the community and to give information about laws that prohibit discrimination on the basis of sexual orientation.

Homosexual tendencies may be biologically determined, however such environmental influences precipitate the actual homosexual behavior by reducing the stigma and inner hesitation. Withholding permission for our children to take part in gay positive events such as open discussion about homosexual behavior as a normal behavior and showing documentaries or movies related to homosexuality, will not protect them from the promotion of homosexuality. Hundreds of web pages are available on the Internet supporting the Muslim gay/lesbian movement. Muslim gay pride parades are held in different parts of the U.S. Only strong indoctrination of Islamic values can protect a child from these negative influences.

Responsibility of Muslim Parents and Community Good parenting, proper sex education and proper supervision of the children will curtail the homoerotic activities and thus prevent further homosexual behavlor. It is extremely impontant that children develop faith in Islam and belief, in Qur'an as the book of Allah from early childhood. Before a child reaches puberty, he must have a clear understanding of the moral teachings of Islam and the prohibition of homosexual behavior and heterosexual relationship prior to marriage. They must be taught about the prescribed punishment by the shari' $a$ and the punishment of such acts after death. Early upbringing with strong faith is the only alternative to cope with the external pressure. Similarly, strong faith is necessary to resist temptation and peer pressure. Even if an individual has homosexual impulses, he should resist acting on it and control the impulses just like the desires to drink alcohol or engage in adultery. Young Muslim adults must develop a strong determination to practice Islam in accordance to the Qur'ān and Sunna (prophetic example) and should not attempt to make homosexual behavior and the moral teachings of Islam compatible.

\section{Role of Clinicians}

Due to recent changes in public attitude, homosexual behavior is no longer secret. Many Muslims who have homosexual tendencies are now expressing their feelings. As a clinician, I have seen a number of
Muslim individuals with homosexual tendencies. some are extremely hesitant to discuss and come for consultation to get an opinion for a 'friend' who has homosexual tendencies. Few openly discuss their feelings. I divide these individuals into four groups:

1. There are individuals with homosexual orientation who never express their feelings, do not engage in homosexual acts, and lead a normal life without experiencing guilt and shame.

2. Those who have homosexual feelings but feel guilty about expressing them. They live with persistent guilt, as they cannot overcome the homosexual feelings. They seek help to overcome the guilt feelings, as they are ashamed of having and expressing these feelings.

3. There are others who have homosexual feelings and strongly feel that they cannot overcome these feelings, and thus seek support and guidance to either change their sexual orientation or live without the guilt and shame.

4. There are others who openly practice homoA clinician cannot helpan individual who hides his feelings and does not want to discuss his issues or seek counseling. Similarly, a clinician cannot help an individual who openly practices homosexual behavior and does not want to make any changes.

A clinician can assist individuals who share their homosexual feelings and seek counseling. We can divide these individuals in two groups:

1. Those who accept that they have homosexual feelings and want to change. Usually, these patients experience extreme guilt feelings and preoccupation with the concept of sin associated with homosexual feelings.

2. Those who have homosexual feelings and believe they cannot change. But they do not want to indulge in homosexual behavior and want to lead a life without feelings of guilt.

The individuals in this second group have a dilemma. They feel guilty about sharing their sexual feelings with the family members. However, if they hide the lack of sexual feelings for the opposite sex, their 
See partial retraction dated July 4, 2015 at http://dx.doi.org/10.5915/44-1-14774

families insist on arranging their marriage. The clinician has to deal with the issues delicately without causing further trauma. In a few cases, I have called the family members with the permission of patients for counseling and educated them about the biological factors responsible for the lack of feelings for the opposite sex.

The main goal of therapy is preventing the feelings of guilt associated with homosexual feelings and helping the individual continue their religious practices and lead a moral life without sexual indulgences.

In addition, for patients who want to change their homosexual feelings, a clinician must learn and have experience in aversion therapy and other therapeutic modalities to change the homosexual feelings to heterosexual feelings. In any case, the clinician must not be judgmental. If he/she cannot handle the case, it must be referred to the appropriate clinician.

It must be clearly stated that there is a difference between homosexual feelings and acts. If an individual does not have-sexual feelings towards the opposite sex, but experiences sexual feelings towands individuals of the same sex, he/she can live a normal life without marriage and without engaging in homosexual acts. This will reassure and remove the feeling of guilt.

\section{Conclusion}

Sexual desires are natural but Islam has given us clear guidelines for the expression of these desires and as well as for self-restraint. An unmarried couple cannot have sexual relations even if the culture and society approve such an act. Similarly, homosexual activity is strictly prohibited even if the individual has homosexual orientation. Endurance, patience and self-restraint are necessary to achieve satisfaction in life. Immediate gratification without paying attention to morals and values leads to social and moral problems and the decay of moral behavior. Allah has warned us and given us prohibitions of adultery, incest and homosexual behavior. Without such religious teachings, people commit such acts in ignorance of the consequences. For example, homosexuality, promiscuous heterosexual relationships and drug abuse lead to many debilitating and sometimes fatal illnesses such as hepatitis B, hepatitis C,
VD, AIDS and other sexually transmitted diseases. The current fear is that, without vaccine or other effective treatment, AIDS may become widespread all over the world. Obeying Allah's laws regarding marriage and sex will reduce the occurrence of such serious diseases. The only way to attain the peace of mind is prescribed in the Qur'ānic inscription and that is to follow the moral laws of Allah as revealed in Qur'ān.

\section{References}

1. Kinsey AC, Pomeroy WB, Martin CE. Sexual behavior in human males. Philadelphia, PA: WB Saunders; 1948.

2. Ford CS, Pattern of sexual behavior. New York: Harper; 1951.

3. Herdt G. Cross-cultural forms of homosexuality and the concept "gay." Psychiatr Ann. 1988

Jan;18(1):37-9.

4. Hamer DH, Hu S, Magnuson VL, Hu N, Pattatucci AM.A linkage between DNA markers on the X chromosome and male sexual orientation. Science. 1996 Jul 16;261(5119):321-7.

5. King M. McDonald E. Homosexuals who are twins. A study of 46 probands. Br J Psychiatry. 1992
Mar,160:407-9.
6. Mann C. Genes and behavior. Science. 1994 Jun 6. Mann C. Genes and

7. Hatterer LJ. Changing homosexuality in the male; treatment for men troubled by homosexuality. New York: McGraw Hill, 1970.

8. Remafedi G. Suicide and sexual orientation: nearing the end of controversy?. Arch Gen Psychiatry. 1999 Oct:56(10):885-6.

9. Fergusson DM, Horwood LJ, Beutrais AL. Is sexual orientation related to mental health problems and suicidality in young people?. Arch Gen Psychiatry. 1999 Oct;56(10):876-80.

10. Herrell R, Goldberg J, True WR, Ramakrishnan V et al. Sexual orientation and suicidality. Arch Gen Psychiatry. 1999 oct:56(10):867-74.

11. Glorious Qur'ān, 26:160-75.

12. Glorious Qur'ān 7:84. See also 11:82-3 and 29:28-9. 13. Musnad Al-Imām Ahmad b. Hanbal. Vol. 1. Musnad 'Abd Allah b. al-'Abbās b. 'Abd al-Muțțalib. 14. Glorious Qur'ān, 24:31.

15. Doi AR. Shari $\overrightarrow{1}$ ah: the Islamic law. London, UK: Ta Ha Publishers; 1984. pp. 237-47.

16. Spitzer RL. Annual Convention of American Psychiatric Association، 2002. 